\title{
Monika Wojtas"
}

Uniwersytet Marii Curie-Skłodowskiej w Lublinie

\section{PRZYCZYNY SPOWOLNIENIA ŚWIATOWEGO HANDLU}

\section{Streszczenie}

Celem opracowania jest analiza źródeł spowolnienia handlu światowego, które wystąpiło od 2012 roku, i określenie jego najważniejszych przyczyn. Głównym czynnikiem spowolnienia wydaje się być cykliczność gospodarki, doszukiwać się go można także w obniżeniu globalnego popytu wywołanego ograniczonym wzrostem inwestycji przedsiębiorstw. Jednak nie da się wyjaśnić tego zjawiska w całości za pomocą czynników o charakterze cyklicznym. Do najważniejszych niecyklicznych przyczyn stagnacji stóp wzrostu handlu należą: obniżenie dochodowej elastyczności handlu światowego, spadek tempa liberalizacji handlu i wzrost protekcjonizmu, zmiana podejścia Chin do wzrostu gospodarczego oraz wyczerpanie się dalszych możliwości rozwoju globalnych łańcuchów wartości.

Słowa kluczowe: handel światowy, globalne łańcuchy wartości, protekcjonizm, stagnacja

\section{Wprowadzenie}

Światowy handel od zakończenia II wojny światowej rozwijał się bardzo dynamicznie, a stopy wzrostu eksportu znacznie przewyższały tempo wzrostu światowej produkcji czy PKB. Jednak tempo wzrostu światowych obrotów handlowych

\footnotetext{
*Adres e-mail: monika.wojtas@poczta.umcs.lublin.pl.
} 
w ostatnich latach zdecydowanie spadło. Dynamiczny rozwój handlu przerwany został przez wybuch kryzysu finansowego i gospodarczego w latach 2008-2009, który przyczynił się do znaczącego załamania obrotów. Mimo szybkiej odbudowy wartości handlu w latach 2010-2011, od 2012 roku można obserwować zdecydowane spowolnienie tempa wzrostu wymiany międzynarodowej, a w 2015 roku zanotowano spadek w wartościach absolutnych (rys. 1). Wywołało to dyskusję na temat możliwości dalszego rozwoju handlu międzynarodowego, przyczyn niskiej stopy wzrostu światowego eksportu i importu oraz potencjalnego wpływu spowolnienia na koniunkturę gospodarczą na świecie w sytuacji, gdy popyt zewnętrzny odgrywa ważną rolę jako czynnik wzrostu gospodarczego.

Celem opracowania jest analiza źródeł spowolnienia handlu światowego i próba wskazania najważniejszych przyczyn obniżenia stóp wzrostu globalnego eksportu i importu. Czynniki niskiego tempa wzrostu handlu mogą mieć charakter cykliczny i wynikać z osłabienia koniunktury, a w takiej sytuacji prognozy dotyczące ożywienia gospodarczego będą miały bezpośrednie przełożenie na poprawę sytuacji w handlu. Jednak stagnacja obrotów może być też konsekwencją głębszych zmian o charakterze strukturalnym, a nie makroekonomicznym, i zahamowania procesu globalizacji, do których można zaliczyć: obniżenie dochodowej elastyczności handlu światowego, spadek tempa liberalizacji handlu i wzrost protekcjonizmu, zmiany podejścia Chin do wzrostu gospodarczego i koncentracja uwagi na rynku wewnętrznym oraz wyczerpanie się dalszych możliwości rozwoju globalnych łańcuchów wartości.

\section{Eksport światowy od 2012 roku}

Światowy handel uległ załamaniu w efekcie globalnego kryzysu, który wybuchł w Stanach Zjednoczonych w 2008 roku. W efekcie wartość eksportu światowego w 2009 roku spadła o 22,25\%. Jednak załamanie było krótkotrwałe i stopa wzrostu w latach 2010 i 2011 wynosiła odpowiednio 21,9 i 19,9\%. W okresie przed kryzysem stopy wzrostu eksportu przewyższały dwukrotnie stopy wzrostu PKB, dużo głębsze było także załamanie obrotów. Od 2012 roku tempo wzrostu światowego eksportu było zdecydowanie niższe. Średnia stopa wzrostu w latach 2012 2014 wyniosła 1,18\%, natomiast w roku 2015 zanotowano spadek, który wynosił $12,87 \%$ (rys. 2). 
Rysunek 1. Wartość eksportu światowego w latach 2005-2015

(w mln USD w cenach bieżących)

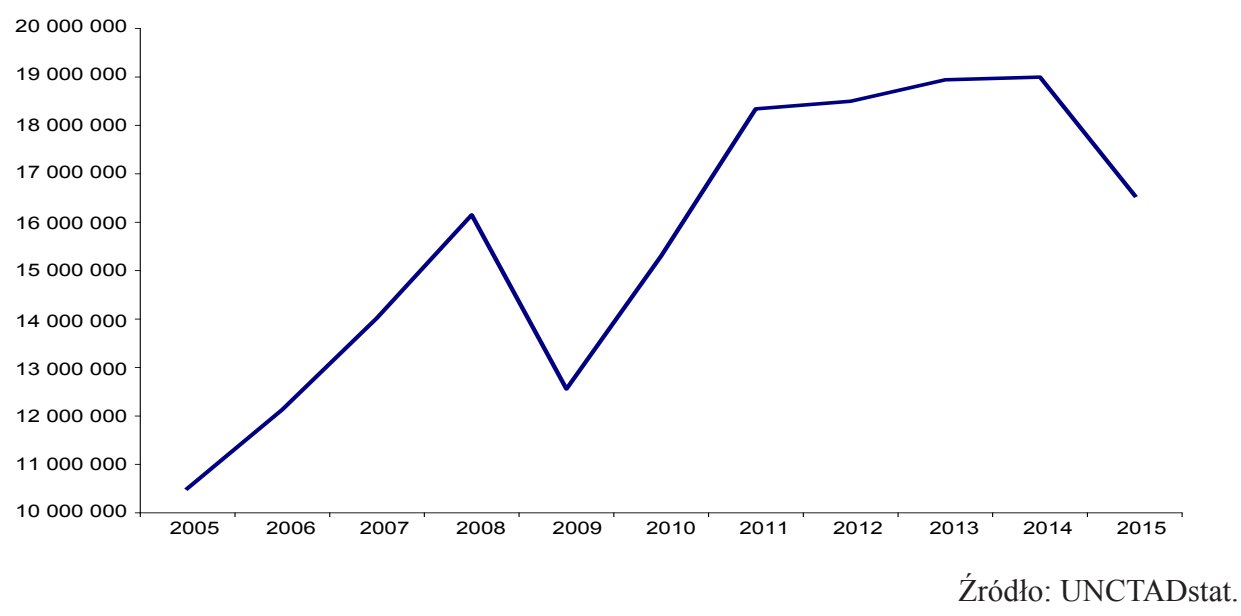

Spadek wartości eksportu w roku 2015 można w dużej mierze wytłumaczyć spadkiem cen surowców oraz zmianami kursów walut. Największy spadek cen zanotowano w przypadku paliw (o 63\% w okresie od czerwca 2014 do grudnia 2015 r.) i był on efektem wzrostu znaczenia alternatywnych źródeł energii oraz spowolnienia gospodarczego, zwłaszcza w Azji, i spadku popytu na surowce energetyczne. Mniej spektakularne spadki cen zanotowano także w przypadku innych surowców, np. metali (o 35\%) czy produktów rolnych (22\%). Spadkom cen towarzyszyła aprecjacja kursów walutowych, m.in. dolara amerykańskiego i chińskiego yuana. W okresie od czerwca 2014 do grudnia 2015 roku aprecjacja dolara wyniosła 19\%, a yuana $13 \%$. Efektem było pogorszenie konkurencyjności cenowej chińskiego eksportu, które przyczyniło się do obniżenia stopy wzrostu gospodarczego (WTO, 2016, s. 19).

Jednak analiza wzrostu eksportu w ujęciu wolumenowym (rys. 2) także ujawnia niepokojące tendencje. Średnioroczne tempo wzrostu eksportu w latach 19932007 wynosiło 7,2\% i było ponad dwukrotnie wyższe od tempa wzrostu globalnego produktu (3,1\%). Tymczasem w latach 2012-2015 średni roczny wzrost wolumenu eksportu wynosił 3,3\%, a więc niewiele więcej niż średnie roczne tempo wzrostu PKB (Jean, 2017). 
Rysunek 2. Tempo wzrostu wartości i wolumenu światowego eksportu i realnego PKB w latach 2005-2015 (\%)

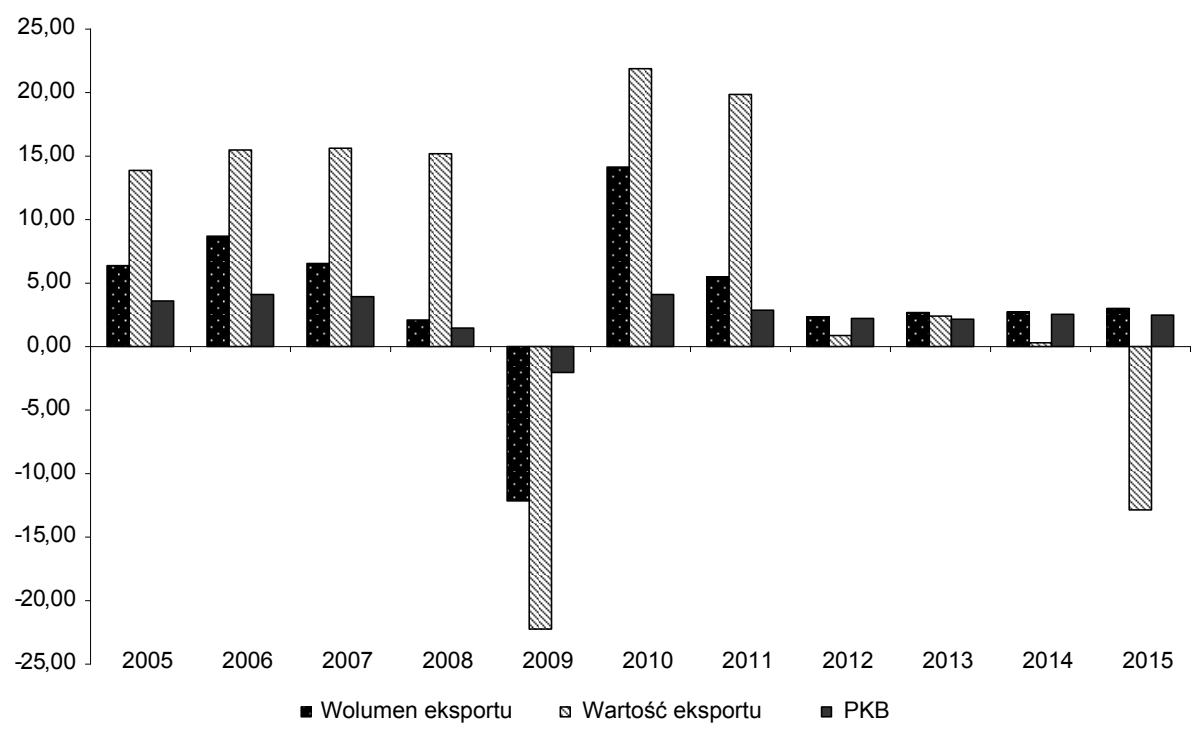

Źródło: UNCTADstat i WTO Statistical Database.

Utrzymanie niskiego, ale stabilnego tempa wzrostu wolumenu światowego eksportu w latach 2012-2015 związane było ze zmianą wkładu poszczególnych regionów geograficznych. W latach bezpośrednio po kryzysie szybka odbudowa eksportu była możliwa dzięki rynkom azjatyckim. Azja miała też największy wkład we wzrost światowego eksportu w latach 2012-2013. Wysoki popyt na importowane dobra i usługi, zwłaszcza na rynku chińskim, skutecznie równoważył spowolnienie gospodarcze w krajach rozwiniętych, w tym szczególnie w strefie euro. Wzrost importu do Chin w latach 2012 i 2013 wynosił odpowiednio 3,5 i 10\%, wysokie stopy wzrostu notowane były także w innych krajach rozwijających się (por. tab. 1). W 2013 roku wkład Azji do wzrostu światowego importu wynosił 73\%. Sytuacja zmieniła się w latach 2014-2015, kiedy wzrost popytu w krajach europejskich i Ameryce Północnej zrównoważył spadek importu krajów rozwijających się. W szczególności dotyczyło to eksporterów surowców oraz krajów azjatyckich, których udział we wzroście światowego importu spadł w 2015 roku do 25\%. Jeśli chodzi o wzrost wolumenu światowego eksportu, to największy wkład w latach 2012-2014 miały kraje Azji (35\%), a w roku 2015 - Europa (44\%). Z wymienionych 
w tabeli 1 obszarów wszystkie, z wyjątkiem Europy oraz Japonii (por. Pasierbiak, 2016), zanotowały niższe tempo wzrostu (lub nawet spadek) eksportu i importu w 2015 roku w porównaniu do roku 2014 (WTO, 2016, s 19-21).

Tabela 1. Tempo wzrostu wolumenu eksportu i importu na świecie, w wybranych regionach i krajach (\%)

\begin{tabular}{|l|r|r|r|r|r|r|r|r|}
\cline { 2 - 10 } \multicolumn{1}{c|}{} & \multicolumn{4}{c|}{ Eksport } & \multicolumn{4}{c|}{ Import } \\
\cline { 2 - 10 } \multicolumn{1}{c|}{} & 2012 & 2013 & 2014 & 2015 & 2012 & 2013 & 2014 & 2015 \\
\hline Świat & 2,5 & 2,5 & 2,7 & 3,0 & 2,0 & 2,0 & 2,8 & 2,4 \\
\hline Ameryka Północna & 4,5 & 3,0 & 4,1 & 0,8 & 3,0 & 1,0 & 4,7 & 6,5 \\
\hline Kanada & 3,5 & 2,0 & 5,6 & 4,4 & 1,5 & 1,5 & 2,8 & 0,7 \\
\hline Meksyk & 8,5 & 4,5 & 6,6 & 4,0 & 7,5 & 3,0 & 6,9 & 13,3 \\
\hline USA & 4,0 & 2,5 & 3,1 & $-0,9$ & 3,0 & 1,0 & 4,7 & 6,5 \\
\hline Ameryka Południowa & 0,5 & 1,5 & $-1,8$ & 1,3 & 2,5 & 3,0 & $-2,2$ & $-5,8$ \\
\hline i Środkowa & 1,0 & 1,5 & 2,0 & 3,7 & $-2,0$ & $-0,5$ & 3,2 & 4,3 \\
\hline Europa & 0,5 & 1,5 & 1,9 & 4,0 & $-2,0$ & $-1,0$ & 3,5 & 4,5 \\
\hline UE-28 & 1,0 & 1,0 & 0,2 & $-0,6$ & 7,0 & $-1,5$ & $-9,6$ & $-21,9$ \\
\hline WNP & 6,2 & $-2,4$ & $-2,1$ & 0,1 & 13,1 & 5,4 & 4,2 & 1,3 \\
\hline Afryka & 4,7 & 1,8 & 0,7 & 8,6 & 9.9 & 5,9 & 2,3 & $-1,9$ \\
\hline Bliski Wschód & 3,0 & 4,5 & 4,8 & 3,1 & 3,5 & 4,5 & 3,3 & 1,8 \\
\hline Azja & 6,0 & 7,5 & 6,8 & 4,6 & 3,5 & 10,0 & 4,0 & $-4,2$ \\
\hline Chiny & 0,0 & 7,5 & 3,5 & $-2,1$ & 7,0 & $-3,0$ & 4,2 & $-8,9$ \\
\hline Indie & $-1,0$ & $-2,0$ & 1,5 & 2,2 & 4,0 & 0,5 & 1,5 & 2,7 \\
\hline Japonia & 1,0 & 3,0 & 3,8 & 0,9 & 2,0 & 3,5 & 2,9 & 1,2 \\
\hline Azja Południowo-Wschodnia & & & & & & & \\
\hline
\end{tabular}

Źródło: opracowanie własne na podstawie WTO (2016, tab. A02); WTO (2014, tab. I02).

\section{Cykliczne przyczyny spowolnienia handlu światowego}

Cykliczne czynniki związane z dekoniunkturą gospodarczą i niepewnością co do perspektyw rozwoju, a przede wszystkim znaczenie w zagregowanym popycie komponentów o dużej importochłonności, do których należą inwestycje przedsiębiorstw, są przez wielu ekonomistów uważane za główne źródła spowolnienia światowych obrotów handlowych.

Komponentem popytu krajowego w znacznym stopniu przyczyniającym się do wzrostu importu są inwestycje przedsiębiorstw. Według dostępnych badań wynika to m.in. z faktu, że dobra kapitałowe mogą mieć bardziej specjalistyczny charakter 
i niekoniecznie być łatwo dostępne lokalnie, a przedsiębiorstwa w porównaniu do gospodarstw domowych mają łatwiejszy dostęp do międzynarodowych rynków. Dlatego wolniejszy wzrost inwestycji w porównaniu do pozostałych składników popytu uzasadnia spowolnienie wzrostu handlu (Jaaskela, Mathews, 2015, s. 41). Na rysunku 3 przedstawiono wzrost wydatków rządowych, konsumpcji i inwestycji w krajach OECD w latach 2005-2018, z którego wynika, że załamanie inwestycji w czasie kryzysu było najgłębsze, a ich wzrost w czasie ożywienia - najwolniejszy. Prognozy na lata 2017-2018 przewidują przyspieszenie tempa wzrostu inwestycji.

Szczególnie istotne z punktu widzenia dynamiki handlu jest spowolnienie gospodarcze w strefie euro (Mucha-Leszko, 2016) i Stanach Zjednoczonych, a w ostatnim czasie także w Chinach. W sytuacji, gdy kraje rozwinięte odpowiadają za około $60 \%$ światowego importu, a Chiny za około $10 \%$, dekoniunktura gospodarcza i spadek popytu na import generowanego przez te kraje powoduje poważne konsekwencje. Szacunki Banku Światowego i MFW (IMF and World Bank, 2015) mówią o globalnym produkcie niższym o 4,5 p.p. w stosunku do trendu przed kryzysem, a w przypadku USA i strefy euro odpowiednio niższym o 8 p.p. i 13 p.p. w 2015 roku.

Rysunek 3. Wydatki rządowe, konsumpcja i inwestycje w krajach OECD w latach 2005-2018

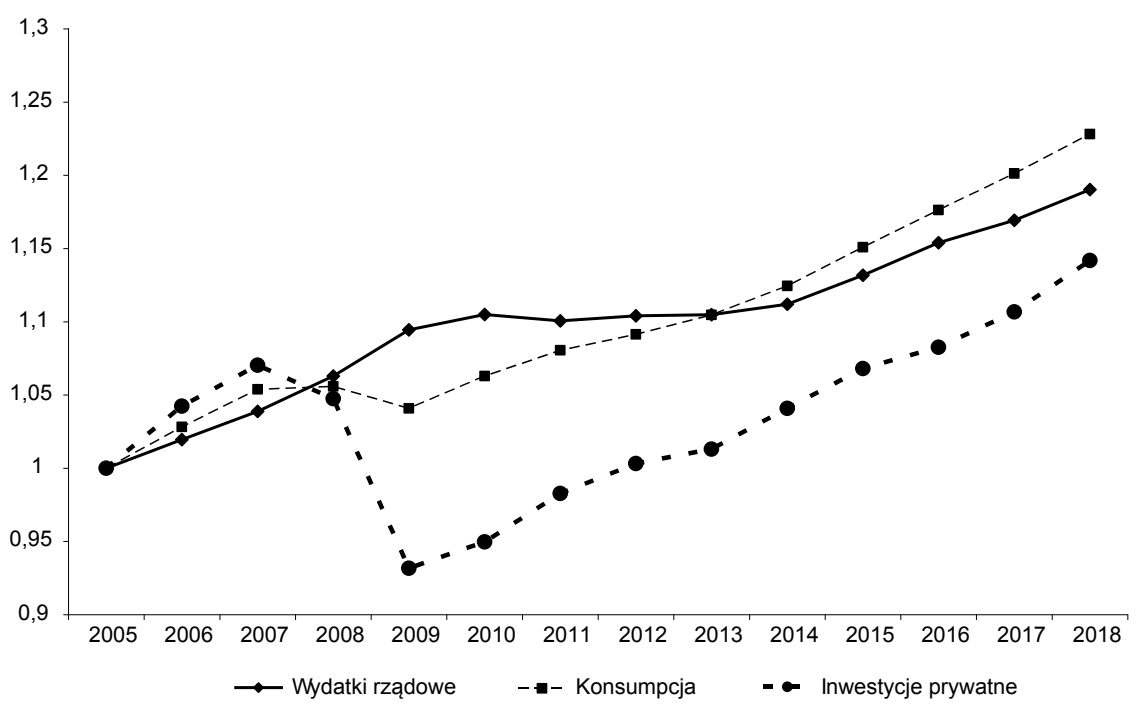

Źródło: OECD (2017). 
Analizy Międzynarodowego Funduszu Walutowego (IMF, 2016) wydają się potwierdzać tezę o cykliczności przyczyn spowolnienia handlu. Wykorzystano relacje między wolumenem importu produktów i usług a zagregowanym popytem w latach przed kryzysem (1985-2007 i 2003-2007) do oszacowania potencjalnego tempa wzrostu importu w latach 2012-2015. Wniosek z analizy był następujący: 85\% spowolnienia światowego importu było spowodowane sytuacją makroekonomiczną na świecie, a zwłaszcza niskim wzrostem inwestycji i eksportu. Świadczy to o silnym powiązaniu pomiędzy wielkością eksportu i importu w warunkach globalnej fragmentaryzacji produkcji, a także szerokim zasięgu, a wręcz globalnej synchronizacji, spowolnienia gospodarczego na świecie. Do podobnych wniosków doszli także P. Ollivaud i C. Schwellnus (2015), wskazując importochłonne składniki popytu, do których zaliczają inwestycje i konsumpcję dóbr trwałego użytku, za główne czynniki spowolnienia handlu. Dane empiryczne wskazują także, że udział dóbr kapitałowych w globalnym imporcie obniżył się z 35\% w 2000 roku do 30,1\% w 2014 (UN, 2016). Gangnes, Ma i Van Assche (2015) oraz Taglioni i Zavacka (2013) wskazują także na istotne znaczenie niepewności co do perspektyw rozwoju jako czynnik ograniczający handel - w warunkach niepewnych prognoz gospodarczych właściciele kapitału ograniczają inwestycje do czasu, aż perspektywy się poprawią.

Wśród cyklicznych czynników powolnego wzrostu handlu wymienia się także problemy w dostępie do zewnętrznych źródeł finansowania działalności handlowej. Według Europejskiego Banku Centralnego (ECB, 2016), w okresie dekoniunktury, gdy dostęp do kredytu i warunki finansowania są utrudnione, ma to szczególnie negatywny wpływ na sektory aktywnie uczestniczące w handlu zagranicznym jako najbardziej uzależnione od zewnętrznego finansowania. Takie problemy wystąpiły w okresie kryzysu w 2009 roku, brak jednak empirycznego potwierdzenia tego zjawiska w latach 2012-2015.

\section{Strukturalne czynniki spowolnienia handlu}

Strukturalne przyczyny niskiego tempa wzrostu globalnego handlu to, z braku lepszego określenia, wszelkie czynniki niepowiązane bezpośrednio z bieżącą sytuacją makroekonomiczną, a zatem czynniki niecykliczne. Przytoczone badania nad cykliczną naturą spowolnienia obrotów handlu światowego wskazują, że nie da się wyjaśnić tego zjawiska w całości za pomocą czynników o charakterze cyklicznym. 
Dlatego też pojawiają się próby innego wyjaśnienia (Boz, Bussière, Marsilli, 2015). Wśród tego typu przyczyn wymienia się obniżenie dochodowej elastyczności handlu w rezultacie zmiany struktury polegającej na wzroście udziału produktów o niższej elastyczności. Próbuje się też wskazywać na wzrost udziału w tworzeniu PKB i w handlu krajów rozwijających się, które charakteryzują się niższą elastycznością, lub spowolnienie konwergencji dochodów na świecie bądź zmiany udziału konsumpcji i inwestycji w PKB. Hipotezy te pozostają jednak niepotwierdzone, a dostępne badania empiryczne odnoszą się bardziej do załamania handlu w okresie kryzysu, a nie obecnej sytuacji (Constantinescu, Mattoo, Ruta, 2015).

Przyczyną wzrostu dochodowej elastyczności handlu w latach 90. XX wieku może być integracja z gospodarką światową krajów Europy Środkowo-Wschodniej oraz Chin, której zakończenie powoduje, że wzrost handlu będzie się odbywał w większym stopniu w tempie zbliżonym do wzrostu gospodarczego. Zwłaszcza wkład Chin do wzrostu światowych obrotów handlowych był ogromny. Od kryzysu Chiny zaczęły jednak wprowadzanie zmian w funkcjonowaniu gospodarki. Nowy model wzrostu - zamiast inwestycji i eksportu - jako główne motory wzrostu wskazuje popyt wewnętrzny i innowacyjność (Pei, Yang, Yao, 2015, s. 253) W efekcie tempo wzrostu handlu zagranicznego w roku 2015 wyniosło jedynie 1,5\% (Haugh i in., 2016, s. 21). Gaulier, Santoni, Taglioni i Zignago (2015) wskazują, że dynamiczny wzrost handlu przed kryzysem był wynikiem szoku podażowego spowodowanego konkurencją cenową produktów z Chin, która prowadziła do zastępowania krajowej produkcji importem. Należy to zatem traktować jako sytuację wyjątkową i oczekiwanie, że w normalnych warunkach (bez pojawienia się szoków technologicznych lub istotnych zmian w kosztach handlu) elastyczność dochodowa będzie większa od 1, nie jest uzasadnione. Wątpliwości co do uznania obniżenia elastyczności dochodowej handlu za przyczynę spowolnienia gospodarczego wyrażał także P. Krugman (2015).

Grupa ekonomistów próbuje także wskazać wzrost protekcjonizmu jako przyczynę spowolnienia $\mathrm{w}$ globalnym handlu, choć w tym przypadku pojawiają się również głosy, że znaczenie polityki handlowej było niewielkie. S. Evenett i J. Fritz stwierdzają, że protekcjonizm ma duży wpływ na ograniczenie tempa wzrostu handlu zwłaszcza w przypadku wybranych krajów (Evenett, Fritz, 2015a) czy sektorów (stal) (Evenett, Fritz, 2015b) oraz że rośnie znaczenie zakłócających handel praktyk, które polegają na subsydiowaniu krajowych przedsiębiorstw, a nie na ustanawianiu 
barier importowych. Problemem w oszacowaniu znaczenia handlu pozostaje fakt, że obecnie stosowane tzw. mętne formy protekcjonizmu (murky protectionism) nie pozwalają na do końca skuteczne monitorowanie i mierzenie ich dotkliwości (por. Wojtas, 2015). Próbę oceny wpływu poziomu liberalizacji podjęli eksperci OECD (Haugh i in., 2016), którzy skonstruowali Globalny Indeks Liberalizacji Handlu (Global Trade Liberalization Index). Za jego pomocą dowodzą, że intensywna liberalizacja handlu w latach 90. przyczyniała się istotnie do przyśpieszenia jego wzrostu rocznie o 2 p.p. i na tej podstawie stwierdzają, że wyhamowanie postępów w liberalizacji handlu ma wpływ na jego tempo wzrostu.

Ocena restrykcyjności obecnie stosowanych instrumentów polityki handlowej nie jest łatwa, a to wpływa na możliwości oszacowania jej wpływu na tempo wzrostu globalnych obrotów handlowych. Warto jeszcze wspomnieć o wpływie niepewności w polityce handlowej. Sytuacja gospodarcza, ale także zmiany w polityce gospodarczej związane np. z wyborem Donalda Trumpa na prezydenta Stanów Zjednoczonych czy z Brexitem, wywołują poczucie niepewności co do przyszłych warunków handlu (Jean, 2017). To z kolei, według ostatnich wyników badań, ogranicza decyzje o wchodzeniu na zagraniczne rynki (por. Crowley, Song, Meng, 2016 oraz Handley, Limao, 2016).

Czynnikiem, co do którego istotnej roli w spowolnieniu światowego handlu panuje powszechna zgodność poglądów (Hoekman, 2015), jest stagnacja w rozwoju globalnych łańcuchów wartości (Global Value Chains - GVC). Fragmentaryzacja produkcji polega na podzieleniu wcześniej zintegrowanej działalności na geograficznie rozproszone bloki produkcyjne. Skutkiem jest powstanie nowych powiązań handlowych pomiędzy krajami zaangażowanymi w proces fragmentaryzacji, co powoduje wzrost obrotów dobrami pośrednimi i podzespołami, który wpływa na wartość i dynamikę eksportu i importu oraz na strukturę przedmiotową wymiany (Białowąs, 2016). Rozwój globalnych sieci produkcyjnych od lat 90. przyczyniał się do znaczącego wzrostu handlu światowego, ponieważ handel mierzony tradycyjnymi metodami (w wielkościach brutto) uwzględnia dobra pośrednie, które często wliczane są do światowych obrotów handlowych wielokrotnie (Białowąs, Wojtas, 2014). Natomiast PKB ze swojej natury opiera się na mierzeniu wartości dodanej, a więc uwzględnia eksport netto. Zatem im większe znaczenie globalnych łańcuchów w gospodarce, tym większy udział handlu światowego w globalnym produkcie. Liczne analizy dowodzą, że rozwój globalnych łańcuchów wartości zdecydowanie zwolnił 
i należy raczej spodziewać się zwrotu w kierunku rozwoju regionalnych sieci produkcyjnych. Dowodem na wyhamowanie rozwoju GVC może być malejący udział dóbr pośrednich w światowym imporcie, który w latach 2011-2015 spadł z 58 do 53\% (Haugh i in., 2016). W większości przypadków wnioski wyciągane są na podstawie tradycyjnej analizy handlu i znaczenia dóbr pośrednich. P. Veenendaal i in. (2015) oraz M. Timmer i in. (2016) podjęli próbę analizy przy wykorzystaniu metodologii wykorzystującej analizę wartości dodanej w handlu. Jednak nie udało im się jednoznacznie udowodnić istotnego wpływu spowolnienia rozwoju globalnych łańcuchów wartości na handel światowy. Należy jednak pamiętać, że dane oparte na wartości dodanej są dostępne z dużym opóźnieniem i w wykorzystanych opracowaniach kończyły się na 2011 roku, a więc nie obejmowały lat, w których wystąpiła stagnacja stóp wzrostu globalnego eksportu i importu. Różne są także poglądy na temat możliwości dalszego rozwoju GVC - od wskazujących na istniejący potencjał w tym zakresie (Baldwin, 2016) do wyczerpania się możliwości ich rozwoju, a nawet wystąpienia refragmentaryzacji, wskazując ponownie dużą rolę Chin i krajów Azji w wyczerpaniu się szans rozwoju łańcuchów wartości (Haugh i in., 2016).

\section{Podsumowanie}

Notowana od 2012 roku stagnacja stóp wzrostu globalnego eksportu i importu wywołała lawinę analiz i komentarzy próbujących wyjaśnić przyczyny tego zjawiska i odpowiedzieć na pytanie, w jaki sposób można z tej sytuacji wyjść. Większość autorów wskazuje na cykliczność gospodarki i głównych źródeł spowolnienia doszukuje się w obniżeniu globalnego popytu wywołanego zwłaszcza ograniczonym wzrostem inwestycji przedsiębiorstw. Zatem ożywienie gospodarcze i pobudzanie koniunktury powinny przyczynić się do poprawy sytuacji. Panuje jednak zgoda co do tego, że nie da się wszystkiego wyjaśnić jedynie wykorzystując czynniki cykliczne. Do najczęściej wymienianych innych przyczyn należą wzrost protekcjonizmu i wolny rozwój globalnych sieci produkcyjnych po kryzysie. Zwraca się uwagę na zmniejszenie stopy wzrostu handlu w porównaniu do stopy wzrostu globalnego produktu, konkludując, że nastąpił spadek dochodowej elastyczności handlu. Podkreślana jest także rola Chin jako głównego motoru wzrostu handlu przed kryzysem, który w związku ze zmianą strategii gospodarczej w ostatnich latach przestał pełnić taką rolę. Problemem, w przypadku oceny znaczenia tych czynników, jest 
trudna mierzalność ich wielkości, a w konsekwencji możliwości ilościowego oszacowania ich wpływu stają się ograniczone. Dotyczy to zwłaszcza nowych form protekcjonizmu w polityce handlowej, ale także globalnych łańcuchów wartości.

\section{Literatura}

Baldwin, R. (2016). The Great Convergence: Information Technology and the New Globalization. Harvard University Press.

Białowąs, T. (2016). Znaczenie globalnych łańcuchów wartości dodanej w rozwoju eksportu krajów strefy euro. Studia Ekonomiczne, 266, 84-95.

Białowąs, T., Wojtas, M. (2014). The Role of Foreign Value Added in Creating Poland's Comparative Advantage in World Merchandise Exports. Annales Universitatis Mariae Curie-Skłodowska. Sectio H. Oeconomia, 48, 31-40.

Boz, E., Bussière, M., Marsilli, C. (2015). Recent Slowdown in Global Trade: Cyclical or Structural? W: B. Hoekman (red.), The Global Trade Slowdown: A New Normal? (s. 55-70). London: CEPR Press.

Constantinescu, C., Mattoo, A., Ruta, M. (2015). The Global Trade Slowdown: Cyclical or Structural? Policy Research Working Paper No. 7158. Washington, DC: World Bank Group.

Crowley, M., Song, H., Meng, N. (2016). Tariff Scares: Trade Policy Uncertainty and Foreign Market Entry by Chinese Firms. CEPR Discussion Paper No. 11722.

ECB (2016). Understanding the Weakness in Global Trade: What Is the New Normal? European Central Bank Occasional Paper Series No 178. September.

Evenett, S., Fritz, J. (2015a). Crisis-era Trade Distortions Cut LDC Export Growth by 5.5\% Per Annum. W: B. Hoekman (red.), The Global Trade Slowdown: A New Normal? (s. 267-278). London: CEPR Press.

Evenett, S., Fritz, J. (2015b). 'Peak Trade' in the Steel Sector. W: B. Hoekman (red.), The Global Trade Slowdown: A New Normal? (303-315). London: CEPR Press.

Gangnes, B., Ma, A., Van Assche, A. (2015), Global Value Chains and the Trade-Income Relationship: Implications for the Recent Trade Slowdown. W: B. Hoekman (red.), The Global Trade Slowdown: A New Normal? (s. 111-126). London: CEPR Press.

Gaulier, G., Santoni, G., Taglioni, D., Zignago, S. (2015). The Power of the Few in Determining Trade Accelerations and Slowdowns. W: B. Hoekman (red.), The Global Trade Slowdown: A New Normal? (s. 93-108). London: CEPR Press.

Handley, K., Limao, N. (2016). Policy Uncertainty, Trade and Welfare: Theory and Evidence for China and the U.S. NBER Working Paper No. 19376. 
Haugh, D. i in. (2016). Cardiac Arrest or Dizzy Spell: Why Is World Trade So Weak and What can Policy Do About It? OECD Economic Policy Papers No. 16.

Hoekman, B. (2015). Trade and Growth - End of an Era? W: B. Hoekman (red.), The Global Trade Slowdown: A New Normal? (s. 3-19). London: CEPR Press.

IMF (2016). World Economic Outlook. Washington, DC. October.

IMF and World Bank (2015). Prospects for Global Trade. WBG IMF G20 Paper.

Jaaskela, J., Mathews, T. (2015). Explaining the Slowdown in Global Trade. Reserve Bank of Australia Bulletin.

Jean, S. (2017). The Slowing in World Trade: A Structural Break, the Cause of Uncertainty. Foundation Robert Schuman European Issue, 421.

Krugman, P. (2015). Explaining Trade Weakness (Wonkish). Op-Ed column for The New York Times.

Mucha-Leszko, B. (2016) Przyczyny słabego ożywienia koniunktury gospodarczej w strefie euro w latach 2010-2015 w świetle hipotezy o nowej sekularnej stagnacji. Prace Naukowe Uniwersytetu Ekonomicznego we Wrocławiu, 449, 436-449.

OECD (2017). OECD Economic Outlook No. 100, 2016/2. Statistics and Projections (database). DOI:http://dx.doi.org.00001ch00178.han.bg.umcs.edu.pl/10.1787/7fa317bf-en.

Ollivaud, P., Schwellnus, C. (2015). Does the Post-Crisis Weakness of Global Trade Solely Reflect Weak Demand? OECD Economics Department Working Papers No. 1216. Paris: OECD Publishing.

Pasierbiak, P. (2016). Institutional Economic Integration in East Asia: Evolution, Assessment and Prospects. International Business and Global Economy, 35 (1), 144-156.

Pei, J., Yang, C., Yao, S. (2015) Trade Impact of China's Transition to the 'New Normal'. W: B. Hoekman (red.), The Global Trade Slowdown: A New Normal? (s. 253-263). London: CEPR Press.

Taglioni, D., Zavacka, V. (2013). Innocent Bystanders: How Foreign Uncertainty Shocks Harm Exporters. ECB Working Paper No. 1530. Frankfurt am Main.

Timmer, M.P., Los, B., Stehrer, R., de Vries G.J. (2016). An Anatomy of the Global Trade Slowdown based on the WIOD 2016 Release. GGDC Research memorandum No. 162. University of Groningen.

UN (2016). World Economic Situation and Prospects 2016. New York: United Nations.

Veenendaal, P., Rojas-Romagosa, H., Lejour, A., Kox, H. ( 2015). A Value-added Trade Perspective on Recent Patterns in World Trade. W: B. Hoekman (red.), The Global Trade Slowdown: A New Normal? (s. 161-178). London: CEPR Press. 
Wojtas, M. (2015). Międzynarodowa polityka handlowa w XXI wieku - główne trendy. Zeszyty Naukowe Uniwersytetu Szczecińskiego. Studia i Prace Wydziału Nauk Ekonomicznych i Zarzadzania, 41 (1), 391-403.

WTO (2016). World Trade Statistics 2016. Geneva: World Trade Organization.

WTO (2014). International Trade Statistics 2014. Geneva: World Trade Organization.

\title{
CAUSES OF GLOBAL TRADE SLOWDOWN
}

\begin{abstract}
The main goal of the paper is to analyze the sources of world trade slowdown since 2012 and point to the main factors contributing to the slowdown. It appears that the major source of the slowdown was cyclical and connected to the lower global aggregated demand due to slow investment activity. However, it does not explain the total extent of the slowdown. Other, non-cyclical, important factors were: lowering of the trade income elasticity, protectionism, rebalancing of the Chinese economy towards domestic market and a halt in the development of global value chains.
\end{abstract}

Keywords: world trade, global value chains (GVC), protectionism, stagnation JEL codes: F1, F44 
